\title{
"CHINA-PAKISTAN ECONOMIC CORRIDOR - HISTORICAL PERSPECTIVE AND FUTURE PROSPECTS OF BALUCHISTAN LINKEDWITH ECONOMIC CORRIDOR"
}

\author{
Mazhar Hafeez ${ }^{1}$, Nazar Hussain², Ghulam Saqib ${ }^{3}$, Shah Muhammad Farooq ${ }^{4}$, Abdul Rehman $^{5}$ \\ ${ }^{1,2}$ Department of Public Administration, Shah Abdul Latif University, Khairpur, Pakistan ${ }^{3}$ Institute of English Language and \\ Literature, University of Sindh Jamshoro, Pakistan ${ }^{4}$ Department of Sociology,Shah Abdul Latif University, Khairpur, Pakistan \\ ${ }^{5}$ Department of Public Administration, Shah Abdul Latif University, Khairpur, Pakistan
}

\section{ABSTRACT:}

This research paper presents an analytical overview of historical perspective of Balochistan andChina Pakistan Economic Corridor (CPEC)considering it as an opportunityfor Balochistan in specific and for Pakistanin generalunder the challenge created by prevailing environment in Balochistan. After discussing historical perspective of Balochistan in detail, this paper will help to identify effects of CPEC with a view to identify impediments causing delay to the project and opportunities which Balochistan has to get benefitted from. An endeavor has been made tooffer few recommendations in last part of the paperin order to suggest measures to negotiate the impediments and utilize this project as an opportunity to change the fate of Balochistan. At present, Balochistan lacks communication infrastructure, safe and secure environment for development activities, skilled and literate populace and requisite ownership to this project.In order toimprove the situation, there is a need to take bold steps in domain of security to maintain safe and secure environment, encourage the developmental activities and at the same time bring transformational changes in policy making so that local population gets maximum benefit out of this project.

Keywords:

Baluchistan, CPEC, Historical perspective of Balochistan, Impediments, Opportunities, Gwadar Port, Pakistan Article Received: 18 October 2020, Revised: 3 November 2020, Accepted: 24 December 2020

\section{INTRODUCTION}

Balochistan; the largest province of Pakistan mainly consists of high mountains,vast barren wastelands and few lush green valleys.If we look towards its geography, it is bordered by Iran and Afghanistan towards west and northwest, towards north it has boundary with provinces of Punjab and KPK, province of Sind towards east and Arabian Sea in the south. Balochistan has longest border i.e. 1,160 kilometers $(\mathrm{km})$ with Afghanistan, $832 \mathrm{kmborder}$ with Iran and $560 \mathrm{~km}$ of coastal area contiguous with the Arabian Sea. If we see it on map of Asia, it appears to be the western-most part of South Asia and dominates the Gulf. Therefore, geographically it carries immense importance thereby making it an area of strategic importance. But if we look towards the history, Balochistan has faced persistentlyan unstable environment and remained a point of distress for the federal and provincial government, politically as well as socioeconomically. Figure 1 shows a map of the Balochistan province.

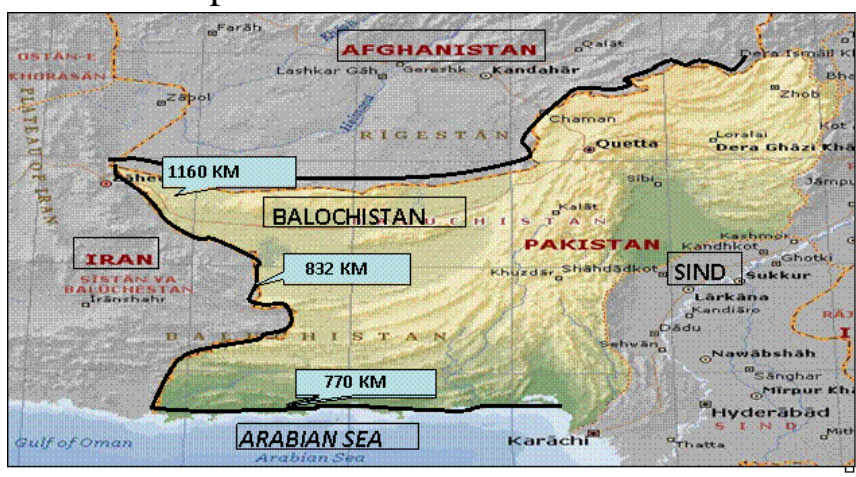

Figure 1 - Geographical location of Balochistan Province

After independence of Pakistan, Khan of Kalat ${ }^{1}$ showed signs of reluctance to join Pakistan,

1 Khan of Kalat: Siddiqi, Farhan Hanif (2012), The Politics of Ethnicity in Pakistan: The Baloch, Sindhi and Mohajir Ethnic Movements. Khan of Kalat, The rulers in Kalat were first subjected to Mughal emperor Akbar in Delhi and later in 1839 to the British 
and then it continued somehow in shape of insurgencies $^{2}$ of 1958 and 1973 and presently remnants still exists in shape of low level uprising in few parts of the province.As of now, issues imitated by the nationalist elements ${ }^{3}$ arebeing fueled by regional powers and international players for their vested interests to create the political scene. Themost dominant factor in the past and to some extent in present times, figures outto be the exploitation of human resource through an age-old "Sardari System". 4

Once China announced mega projects in Gawadar and took keen interest in these mega projects, this attracted foreign powers, regionally and globally, to safeguard theirown interests in this region and exploit the situation to their benefit. In addition, thedisturbed situation in neighboring Afghanistan,acts as a source to further compound the situation in Balochistan.

China officially announced China Pakistan Economic Corridor (CPEC) ${ }^{5}$ under Belt and Road Initiative in May 2013, during the visit of the Chinese Prime Minister to Pakistan.Under the umbrella of CPEC, China and Pakistan agreed to complete energy and infrastructure projects as early as possible. The China-Pakistan Economic Corridor has four parts; ${ }^{6}$ Energy Projects, development of SEZs, Transport Infrastructure and Gawadar Port,thus would become significant source of socio-economic and developmental activities and open new horizons for progress and prosperity of the local populace.

\section{RESEARCH OBJECTIVE}

and held the title of Vali originally but in 1739 they also took the title (Begler Begi) Khan, usually shortened to just Khan. The last Khan of Kalat was also the President of the Council of Rulers for the Baluchistan States Union.

2 Insurgencies of 1958 and 1973: Baluchistan in focus by Rahimullah Yusufzai \& Balochistan, its Strategic importance by Syed Iqbal Ahmed \&"Tribes and Rebels: The Players in the Balochistan Insurgency". Terrorism Monitor. Jamestown Foundation.

3Nationalist elements: Smith, Anthony D.Nationalism: Theory, Ideology and History . Cambridge: Polity Press

4Sardari System: In Baluchistan, the title Sardar marked the chief of his tribe. Balochis of Pakistan: On the Margin of History by The Foreign Policy Centre 5CPEC: "Pakistan receives $\$ 46$ billion investment from China" CNN 20 April 2015

6 CPEC Parts:http://cpec.gov.pk/
The main purpose of the study is to identity the impediments to the CPEC in historical purview of Balochistan and utilize it as an opportunity to bring prosperity to the locals.

\section{LITERATURE REVIEW}

It has been confirmed through archeological discoveries that Balochistan was inhabited since Stone Age especially after discovery of important site Mehrgarh (7000 to 3000 B.C.), oldest in the subcontinent, ${ }^{7}$ regardless of the inherent hostility of its landscape and climate.Balochistan was part of the Persian Empire, ${ }^{8}$ until it was overthrown by Alexander the great, whose records refer to this place as "Maka." In 325 B.C. Alexander, ${ }^{9}$ at the cost of terrible suffering and high casualties, returned his army from Indus campaign to Babylon across the Makran Desert. Thereafter, for centuries, Balochistan remained on thefringes of the Zoroastrian, rulers of Iran, ${ }^{10}$ and the local Buddhist or Hindu dynasties of the northwestern subcontinent. Islam came to Balochistan in 711 A.D. with arrival of army of Muhammad bin Qasim $^{11}$ across the Makran route and in Sindh province, however the area was too remote for steady control to be exercised by any of the later local empires or dynasties. ${ }^{\mathbf{1 2}}$

\section{- Historical Perspective}

In recent pastBaloch came into power once Brohis succeeded in re-establishing their power in Kalat durine era of Mughals, but not for a very long duration. The Khanate of Kalat were the leading local power in $18^{\text {th }}$ century and with the passage of time Baloch tribes settled to the western side

7Mansoor Akbar Kundi, "Tribalism in Balochistan: A Comparative Study," in Tribal Areas of Pakistan: Challenges and Responses (Islamabad: Islamabad Policy Research Institute and Hanns Seidel Foundation, 2005)

8Dashti, Naseer (2012), The Baloch and Balochistan: A Historical Account

from the Beginning to the Fall of the Baloch State

9Pre Islamic History - History of Balochistan wikipedia

(https://en.wikipedia.org/wiki/History_of_Balochistan\#Pre-Islamic_history)

10 The Diplomat - Brief history article by Akhilesh Pillalamarri

(https://thediplomat.com/2016/02/a-brief-history-of-balochistan/)

11 Muhammad Bin Qasim Predator or Preacher by Akhtar Balouch - Dawn 15

Dec 2020 \& Religion and Society in Arab Sindh by Darryl N. Maclean

12 M. Longworth Dames, "Balochi Folklore," Folklore 13, no. 3 (September

29, 1902): 252-74; Ibn Aseer 3: 17; Tarikh al Khulfa 1: 214-15,229. 
while Mughals got acknowledged their supremacy and controlled the area towards the east, in the subcontinent. Thereafter, Khanate of Kalat controlled the western part almost independently till $1948^{13}$ once he signed the merger documents with state of Pakistan. In 1955, he formally moved out of power, making Balochistan one of the provinces of the Pakistan.However, till 1973 Sardari system remained in existence in Balochistan in one way or other and first time democratic government of Balochistan province came into being in 1973 in result of 1970 elections. Geographically, the present form of Balochistan was restored in 1958, once Gawadar, given by ancestors of Khan of Kalat, was annexed back after purchasing from Sultan of Oman. In order to understand the dynamics of ongoing environment, it is essential to look more closely at Baluchistan's history,particularly the British era.

In the beginning of $19^{\text {th }}$ century, Russia was in process of moving towards Central Asia, while the British ${ }^{\mathbf{1 4}}$ had established their rule in the subcontinent. The British government in London gotconcerned and anticipated it as a looming threat to the security and serenity of the British Indian Empire and asked their government in India to take solid measures to check the forward movement of Russians. ${ }^{15}$ Thus British began actively involvement in thepolitics of this region thus started to control the security aspects of the region. Till this point and time, the area now formed part of Pakistan (i.e. Sindh, Balochistan, Punjab and the North-West Frontier Province) and the tribal belt were almostsovereign and independent.

After gaining their foot hold, British started putting in more energy to further consolidate their hold. To this end, they steereddialogueswith the Khan of Kalat to sign animproved treaty in 1976 at Jacobabad. As anoutcometo this, Quetta and the surrounding area till Bolan Pass was also taken

13Siddiqi, Farhan Hanif (2012), The Politics of Ethnicity in Pakistan: The Baloch, Sindhi and Mohajir Ethnic Movements

14 Syed Iqbal ahmed, Blochistan, its strategic importance (2002)

15 Ansar Abbasi "What Balochistan Deserves," The News International, (Islamabad, September 7, 2006). under control by British on lease. As per agreement,this area was kept under symbolic sovereignty of Khan of Kalat but on ground it was controlled by the British rule. A British Indian force gotplaced at Quetta and Sir Robert Sandamen was employed as the first mediatorto the Governor General in Balochistan. He insightfully established contacts with the tribal chiefs and did well in keeping peace in the area. The practicecame out to be known as the Sandamen System or the Khasadar System.

Balochistan comprised of four princely states at the time of independence in 1947 i.e. Kalat, Lasbela, Mekran and Kharan. Kalat also acceded to Pakistan, once other three princely states did it, leaving no option for Kalat as it became land locked from all sides. Even after independence,British policy of administering the Balochistan through Maliks and Sardars was continued till 1970 elections and Balochistan first emerged with elected government in 1973, once reins of power of the country were handed over to Zulfiqar Ali Bhutto by president Yaya Khan after 1971 debacle.

The current situation in Balochistan needs to be seen with political, economic and socialdimensions. At the same time, the factor of foreign intervention and situation in Afghanistan figures out to be the root cause of the trouble which led to the problem. Politically, Balochistan remainedhandicapped for a considerable time and did not get the status of a province for a quarter of a century after independence ${ }^{\mathbf{1 6}}$ as its first provincial assembly was elected in result of the 1970 elections conducted during Yahya's ${ }^{17}$ regime.

16 Abbasi, "What Balochistan Desrves."

17 General Agha Muhammad Yahya Khan was born at Chakwal in February 1917. After completing his studies from the Punjab University, Yahya Khan joined the Indian Military Academy at Dehra Dun. He was commissioned in the Indian Army in 1938. His early postings were in the North West Frontier Province. During World War II, he performed his duties in North Africa, Iraq and Italy. After Independence, Yahya Khan played a major role in setting up the Pakistan Staff College at Quetta. During the war of 1965, he commanded an infantry division. He was appointed Commander-in-Chief of Pakistan Army in 1966 with the rank of General. When, in 1969, countrywide agitation rendered the situation out of control, Ayub Khan decided to hand over power to the Army Chief, General Yahya Khan. Immediately after coming to power, Yahya Khan declared Martial Law in the country on March 25, 1969, and assumed the title of Chief Martial Law Administrator. He terminated the Constitution and dissolved the National and Provincial Assemblies. On March 
However, during the government of Zulfikar Ali Bhutto, it was supposed that some of Baloch Sardars were being stimulated and used by foreign influencesprimarilythe Soviet Russia and during this phase weapons being transported for them from Iraq were caught at the Islamabad airport. This incident createda situation of distrust and doubt between the provincial government and the federal government of Prime Minister Zulfikar Ali Bhutto. Resultantly, government of Balochistan was dismissed and military action was initiated in 1973. This act created major impediment to the progress of democratic political process in the province.

Soon after, we saw a shift or return towards the policy of appeasement with Sardars during the government of Zia ul Haq and peace was regained in the province. Then for next few decades, Balochistan experienced more or less the same political evolution as the rest of the country leavingBenazir government when Balochistan assembly was dissolved ${ }^{\mathbf{1 8}}$ in 1988 however, it was reinstated by the High Court. This act of federal governmentinvited lot of bitterness against the Centre.

The province of Balochistan is distinctiveas far as its geo-political significance is concerned. It covers $44 \%(34,056 \mathrm{sq} \mathrm{km})$ of the total mass of country's land and most significantly, it has a $770 \mathrm{~km}$ long coastal line in the south touching Arabian Sea. It consists mostly of barren valleys,numerous mountain ranges and is separated from Indus Plain by the Kirther and Sulaiman ranges. In short, Balochistan contains great variety of terrain, including vast and rocky desert area havingvery low rainfall and of extreme climate making it very hot (more then 50 ${ }^{\circ} \mathrm{C}$ ) in summers and at the same time very low

\footnotetext{
31, he also became President of the Islamic Republic of Pakistan. Immediately after taking charge of the country, he started looking for options through which he could hand over power to the elected representatives. On March 29, 1970, through an Ordinance, he presented an interim Constitution, the Legal Framework Order. It was actually a formula according to which the forthcoming elections were to be organized. It goes to the credit of Yahya Khan that the first general elections in the history of Pakistan were held during his regime in December 1970.

18 Pakistan: Elections held in 1988 Inter-Parliamentary Union (http://archive.ipu.org/parline-e/reports/arc/2241_88.htm)
}

temperature (almost or below freezing point) in winters.

Balochistan lacks industrialization, however, large number of livestock, rich mineral and gas deposits and quality deciduous fruits are of significant value as far as economy of the province is concerned. Most of Balochistan's land is barren but different climatic zones in the province contribute towards rich animal and plantdiversity, while building a differentheritage full of legacy and customs that allowsexistence of life in this craggy and toughcountryside.

Balochistan carries immense strategic value due to its location as it completely dominates Straits of Hormuz, one of the choke points on sea lines of communication. Its geographic importance further increases due to its border with Helmund of Afghanistan and at Chagai with Seistan of Iran in the northwest overseeing the Mashad-ZahedanChabahar Highway. Within the country, Khojak and Bolan Passes (opposite Kandahar of Afghanistan) are some of the most important passes in the region from the geo-strategic point of view and their importance remains alive till todate as it was for Czarist Russia and Victorian England in the past.

Now coming towards political boundaries of Balochistan as these do not conform to its ethnic alignment; instead they differextensively. According to ethnic conformation, the Baloch residetill areasof Helmund, Nemroz of Afghanistan, Seistan of Iran and Sindh, Punjab and KPK province of Pakistan. In fact, large areas of Eastern Iran, Southern Afghanistan and Pakistani Balochistan are so indistinguishable in topography, layout and ecology that they figure out to be one natural region. According to Sir Denys Bray ${ }^{19}$, "Together they appear more Central Asian than Indian."

Now if we talk of present regime, the federal government seems firmand resolute to bring

19Sir Denys de Saumarez Bray, KCSI, KCIE, CBE (29 November 1875 - 19 November 1951) was an etymologist and British colonial civil servant in the Empire of India, who served as Secretary of the Foreign Department of the Government of India1909: The Brahui Language, Part I. Calcutta: Superintendent Government Printing (Reprinted 1977-78, Quetta: Brahui Academy, Bib ID 1174990) 
development and progress to Balochistan. Ventures worth billions of rupees areis in progress as part of the most admired project i.e. CPEC. As far as Balochistan is concerned, one of the most important venture of CPEC is development of Gwadar Port.

\section{- China Pakistan Economic Corridor (CPEC)}

CPEC is important for the development of Balochistan in specific and for development of this complete region as a whole. In fact, CPEC is the only answer to growing strategic compulsions of the China but its strategic effects once obtained will change the fate of this area due to quantum of economic activity which will be generated in this complete region. Balochistan will also get benefitted as lot of development and economic activity will take place here. CPEC projects can be broadly classified into three categories; building and improving transport infrastructure including road and rail networks, developing energy infrastructure and setting of special economic zones (SEZs). Given the energy shortages and road and rails deficiencies, \$64 billion CPEC investment has been distributed $71 \%$ to energy, $21 \%$ to roads and rails development and $4 \%$ to Gawadar port. ${ }^{20}$ Figure 2 shows CPEC routes starting from Gawadar and leading till Khunjrab.

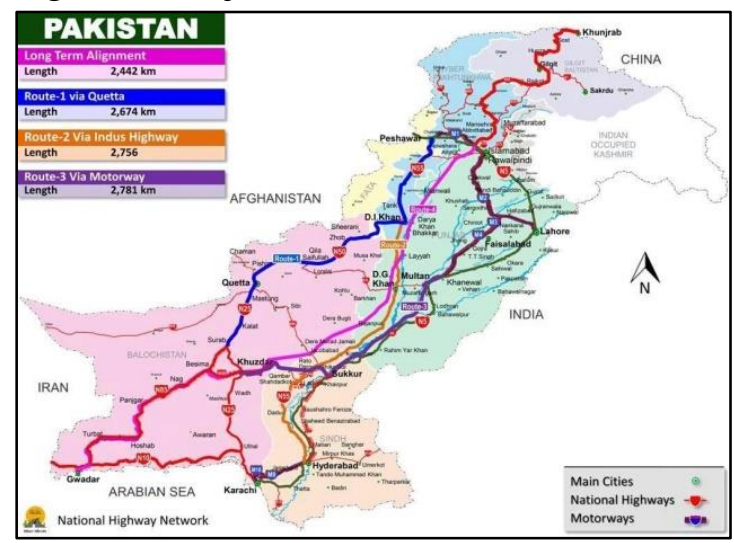

Figure 2- Three CPEC Routes from Gawadar to Khunjrab

Major projects includes road infrastructure covering three routes; Western route starts from

20 T Boyce, "The China-Pakistan economic corridor: Trade security and regional implications," Sandia Report, California. (2017).
Gwadar via Quetta to Dera Ismail Khan, Peshawar, and finally $\mathrm{KKH}$, Central route leads from Gwadar to Khuzdar, Jacobabad, DG Khan, Islamabad and $\mathrm{KKH}$ and Eastern route commences from Gwadar to Khuzdar, Ratodero, Sukkur, Multan, Faisalabad, Islamabad, Havelian and KKH.Railways ${ }^{21}$ development includes improvement and upgradation of ML-1, worth $\$ 8$ billion and ML-2 costingof $\$ 5.5$ billion, completion by 2030.Then the proposed oil and gas pipeline spread over $2500 \mathrm{~km}$ starting from Gwadar Port to Xinjiang.Balochistan specific projects include developing Gwadar Port in terms of depth and capacity. Furthermore, $28 \mathrm{x}$ sites have been planned from Khunjerab to Gwadar for establishment of SEZs, which as medium term projects will be completed by 2025 . Out of these 8 $x$ SEZs are being developed in Balochistan one each at Gawadar, Lasbella, Dera Murad Jamali, Winder, Khuzdar, Bostan and Qilla Saifullah / Zhob or Loralai (feasibility being carriedout). ${ }^{\mathbf{2 2}}$ Impediments

\section{- Political Landscape}

Ethnically Balochistanis divided into two zones i.e. Pashtoon and Baloch zone, creating the dilemma that any upcoming leader from one zone or group is not acceptable to the other group, thus commonor undivided leadership of the province seems to be a rare phenomenon. In past, politics in Balochistan generally kept on revolving around pro and anti-federation elements, wherein subnationalist parties headed by Sardars have taken it to nonfunctional political process at the provincial level thus further upgrading the dominion of local elite. ${ }^{23}$ In short, Balochistannever had a sturdy and steady political government. If we look at the present government, which we may call a collation government is not been able to address

\footnotetext{
21 CPEC Fact Book, $2016 \&$ https://reconnectingasia.csis.org/database/projects/karachi-lahore-peshawar-ml1-rail-lineexpansion-restoration/df56b152-7829-4b70-80fb-7508c42281b0/

22 Source: Ministry of planning, development and reforms, government of Pakistan.

23

https://hrmars.com/papers_submitted/3063/The_Political_Economy_of_Development_A_Cri tical_Assessment_of_Balochistan,_Pakistan.pdf
} 
the core issues in true letter and spirit and element of lawlessness in some areas and lack of speedy developmental activity needs special attention of provincial and central government.

\section{○ Sub-Nationalism}

Historically sub-nationalist drive in Balochistan is linked to pre-independence era once Baloch National Party (BNP), did not agree to accession of the State of Kalat with Pakistan, under patronage of Ghaus Bakhsh Bizenjo. This forced the government to take action against the Khan of Kalat in 1956. This enabled the dissatisfied Baloch leaders to float the idea of greater Balochistan comprising Balochistan province of Pakistan, Seestan o Balochistan ${ }^{24}$ province of Iran and Nimroz and Helmund provinces of Afganistan.

The main reasonsbehind Balochistan'sdeprivation, being circulatedby the Baloch, includesaccusing Punjab of prowling the resources of Balochistan thus rejecting the Punjab's dominance, impeding mega-development projects by believing them contrary to the bigger interests of Balochistan,disseminatingmalicious propaganda against thecentral government that Balochistan with $6 \%$ of the country's total population ${ }^{25}$ is not proportionally represented within the federation as per its geographic size. Accusing the government of being deprived in terms of award of developmental funds through NFC (National Finance Commission) Awards. ${ }^{26}$

\section{○ Socio Economic Status}

24 Trade across Frontiers in Balochistan, naval 21

25

http://www.finance.gov.pk/survey/chapters_19/Economic_Survey_2018_19.pdf 26 NFC Award i.e. National Finance Commission (NFC) award is the distribution of financial resources among the provinces of Pakistan by the federal government on an annual basis. Pakistan has seven NFC awards to-date. The lack of consensus in the National Finance Commission had delayed the announcement of the seventh NFC Award. As a result, the sixth Award, which lapsed in the year 2002, was still being adhered to. Then after a meeting between the president and the chief ministers (CMs), the four $\mathrm{CMs}$ empowered the president to take the final decision. Therefore, now the president has announced the seventh NFC Award through an ordinance. His fresh steps have revealed that the President believes in inter-provincial harmony. Since no consensus could be developed on a new NFC award and for that reason he had decided to offer more money to the provinces through a new resource distribution formula and decided to amend article 160 of the Constitution of the Islamic Republic of Pakistan to make the existing divisible pool more attractive for the federating units.
Sense of deprivation as discussed in above paras, has been created in the province due to lack of inputby previous governments in the socioeconomic development, thus providing apretext to the sub-nationalist parties for divulgencein spreading sentiments against the Punjab and central government. Population of Balochistan seems to be alienated between extremely powerful class of tribal chiefs and illegal business holders. The remaining population consists of lower class and public sector employees ${ }^{27}$ and the most important orthe vibrant segment of society i.e. middle class, which normally uses assertive politics to attain its social and economic securities, is almostnonexistent in Balochistan.

We can say that lack of progress in socio economic sector of the province is mainly due todearth of interaction of people of Balochistan with the people of other provinces. Main contributory factor to this comes out to be theexistence of very less communication infrastructure (Balochistan has $44 \%$ of the land mass of Pakistan, however, has $26 \%$ of black top roads as compared to approximately $28 \%$ in Punjab and $22 \%$ in Sindh and 24\% in KP. ${ }^{28}$ This sense of deprivation is further accentuated due to poor economic conditions as a result of limited agriculture, industry and mining projects, insignificant representation of Balochis in bureaucratic cadres especially in senior ranks and in defense forces, overall unemployment amongst skilled and unskilled individuals, non-availability of adequatecommunal services i.e. electricity, healthcare, clean drinking water, gas and telephone services etc, rather availability of these services is considered as privileges instead of basic necessities. ${ }^{29}$ Last but not the least is the unsubstantiated feeling of discernment in the accountability process.

\section{$\bigcirc$ Smuggling of Oil and Arms}

27 Manzoor Ahmed and Gulawar Khan, "The History of Baloch and Balochistan: A Critical Appraisal," South Asian Studies, 32(1), (2017)

$28 \mathrm{http} / /$ /balochistan.gov.pk/explore-balochistan/about-balochistan/

29Human Rights Commission of Pakistan, hrcp-

web.org/balochistan_mission.cfm.html (accessed July 2007). 
The smuggling in Balochistan is considered a trade activity involving risks and is not considered an illegal or immoral act. Smuggled goods are available in abundance. In past also, efforts putt into prevent this large scale smuggling have not been successful due to lack of other income generating options and also due to ineffective border control mechanism with Afghanistan and Iran. Now, this menace of smuggling of arms and ammunition has added another dimension by adding challenge and disturbance to the internal situation, thus giving air to element of disorder, lawlessness and insecurity in the province. The main reasons for smuggling of Oil from Iran by the locals' are mainly the non-availability of other opportunities in Balochistan ${ }^{\mathbf{3 0}}$ and gettingeasy money with less of the effort.

\section{$\bigcirc$ Poverty and Unemployment}

As per $\mathrm{UNDP}^{31}$ report, more than $70 \%$ of the population in Balochistan is living below poverty level, this percentage is not only alarming in itself but also if we see it in comparison to other provinces of Pakistan, ${ }^{32}$ Balochistan very clearly figures out to be most affected province. The major factor behind this high percentage of poverty is unemployment, regardless of the education or skill level. Thus, deprived and unsatisfied youth of Balochistanspeaks against the federal government for not sticking to to the 'quota' of Baloch. Furthermore, almost nonexistence of industrial activity mainly due toreluctance of Sardars, not allowing progress in developmental works has further exacerbated the situation. Therefore, leaving very few options for the unemployed youth, other thantaking up arms. ${ }^{33}$ The small population of Balochistan can be viewed as an advantage, as with only 1.5 million families, it needs merely 1.5 million total

\footnotetext{
30https://www.dawn.com/news/1489874

31 UNDP Human Development Report, UNDP Human Development Report Office (2015)

32 The Multidimensional Poverty Index (MPI) is a broad measure of understanding and measuring poverty that considers deprivations in education, health, and standard of living along with income and wealth.

33 Balochistan's Youth; Options Open, www.balochistan.org/modules.php.html (accessed July 2007).
}

jobs to employ its entire population, at the rate of one job per family. ${ }^{34}$

The province is predominately a rural population (75\%), it is maximum in comparison to other provinces. Moreover, only $25 \%$ of villages are connected to the power grid, whereas unemployment is also staggeringly high. ${ }^{35}$ The share of the province in the national GDP has been declining over the last two decades. ${ }^{36}$ Taking it wholesomely, performance of the province is far worse than the national average of the country. ${ }^{37}$ For example, after 1970s, its share in the country's GDP has fallen from approx. 5 to less than 3 percent in year $2000,{ }^{38}$ likewise, in 2014-15, the per capita GDP in Balochistan was Rs 31,000, and on the other hand, per capita GDP in Punjab, KPK and Sindh for the same fiscal year, was Rs 54,672, Rs 53,000 and 69,417 respectively. ${ }^{39}$ As labour productivity in Balochistan is also lower than in other provinces of the country, the poor living standardsin Balochistan aretherefore a reflection of joblessness and low output. It is estimated that in every year, out of total, only $8 \%$ of the graduates in Balochistan secure suitable jobs. ${ }^{40}$ Countrywide, the national unemployment rate is $5 \%$, while the youth unemployment rate is $8 \%, 41$ however, in Balochistan, youth unemployment is near to $26 \% .^{42} \mathrm{In}$ short, the

34 Government of Balochistan, "Chief Minister's Policy Reform Unit", Balochistan Development Vision and Strategy (2014).

35 Maria Malik, Balochistan Conundrum.

36 Hafiz A. Pasha, Growth and Inequality in Pakistan (Volume1), (Islamabad: Friedrich Ebert Stiftung, 2018).

37 World Bank, "Pakistan-Balochistan Province: Public Financial Management and Accountability Assessment”, Integrative Fiduciary Assessment No. 39799, (Washington DC: World Bank, 2013).

38 Kaiser Bengali and Aisha Ghaus Pasha, "Pakistan," in Ann L. Griffiths, Handbook of Federal Countries, for Forum of Federation, McGill-Queen University, (2005).

39 Manzoor Ahmed and Akhtar Baloch, Political Economy of Balochistan, Pakistan: A Critical Review. European Scientific Journal, ESJ 11.14. (2015). Hafiz A. Pasha "Growth of the Provincial Economies," Institute for Policy Reforms, Islamabad, Pakistan (2015). http://ipr.org.pk/wp-content/uploads/ 2016/04/GROWTHOF-PROVINCIALECONOMICS-.pdf.

40 Aadil Nakhoda, “The 'E' in CPEC,” Dawn Karachi, 20 March 2016. https://www.dawn.com/news/1246761.

41 UNDP Human Development Report 2015," UNDP Human Development Report Office, (2015).

42 Balochistan Assessment, South Asia Terrorism Portal, 2016, http://www.satp.org/satporgtp/countries/pakistan/Balochistan/in dex.html. 
province has the topmost infant and maternal transience rate, the topmost poverty rate and the lowest literacy rate in the country. ${ }^{\mathbf{4 3}}$

\section{○ Low Literacy Rate}

The literacy portraitof the province is also very much unhealthy and it further adds to the dilemma, once we see that available facilities does not match with the required standards.In addition, politicization of educational establishments and strong student groups do not allow the administration to work effectively. Thus, graduates here in Balochistan are unable to take part in competition at national grid due to less of the proficiency level in their respective fields. In May 2017, it was reported that the literacy rate further shrunk in Balochistan to $41 \%$ in 2016 as compared to $44 \%$ a year earlier. ${ }^{44} \mathrm{In}$ brief, low performance of province in education is not only a function of poverty but mainly due to systematic negligence by successive federal and provincial governments.

\section{○ Mekran Coast}

If we go back only a decade or so, it becomes quite obvious that Mekran was traditionally known to be a peaceful area. But after commencement of work at mega scale on developmental projects, like Coastal Highway and Gwadar Deep Sea Port, it attractedregional and foreign players thus instability was brought in the province by inciting non-state actors from all across the province. ${ }^{45}$ These non-state actors use criminals, who hide in the mountains andtry to sabotage these developmental projects believing that this act of theirs is in better interest of Balochistan and the Baloch.

\section{○ Miscellaneous Factors}

Few of the most prominent factors for this instability and uncertainty comes out to be the low governance, inability to maintainfirm writ in the province and the element of friction or

43Moonis Ahmar, "Strategic Meaning of the China-Pakistan Economic Corridor," Strategic Studies, Vol. 28, No.4 (2014): 35-49.

44http://www.finance.gov.pk/survey/chapters_16/10_Education.pdf

45The Nation, "Balochistan Situation," nation.com.pk/daily/apr-

2005/11/columns3.php (accessed March 2007). resistance between various political parties forming part to make alliance government of the province. Other than these factors, inflow of Afghan refugees,geo-strategic interference from regional and extra regional powers and covert involvement of international powers have some role to play here thus affecting the peace and stability of the province. And last but not the least, almost nonexistencerole of electronic and printedmedia through mature and innovative coverage leaves a big vacuum for misinformation to be exploited by the external players.

\section{Way Forward}

Providing security to citizens is prime responsibility of the government as it is ensured through practical means. To this end, political ferocity and terrorism if exists, it straight away invites both external and inlandfactors to gather and generate threat to state security. Following steps, if taken appropriately by provincial and federal government with correct timelines will definitely bring rich dividends to address the issue:-

\section{- Deliberate planning with proactive approach}

If we closely analyze the situation in Balochistan, it comes quite apparent that sound and objective planning was always lacking while preparing policies and strategies for the province. Most of the policies and strategies were not proactive in nature. Therefore, it is need of the hour to have deliberate, sound and proactive planningrather than sting reactions to the changing situations.

\section{- The wholesome approach}

Balochistan's situation has never attained stability thereby making it a necessity to take appropriate measures while dealing with the issue as a whole. To this end, government should be dealing with Sardari Systemwhile havingpractical approach leading towards political solution of the problem. At the same time, troubled areas are required to be cleaned through kinetic operationswithout having any change to present political status. In parallel, there is a need to undertake massive economic 
uplift, both short and long term at the fast pace. While doing this civil management is to be taken along to ensure their equal foot print in forward areas as well.

\section{- Relations with Afghanistan and Iran}

Pakistan's immediate goal should be to support the peace process in Afghanistan. Afghan government should be taken on board not only by Pakistan government but also by Chinese officials to convince them against colluding with India on CPEC and highlighting the inherent advantages and avenues opening for Afghanistan. Similarly, linking IP gas pipeline to China ${ }^{46}$ and current China-Iran bilateral trade agreement; ${ }^{47}$ Iran should be able to find its way out in linking itself with CPEC by developingChabahar and Gwadar ports.

\section{- Completion of Gwadar Port}

The center piece of the corridor is the development of Gwadar as deep sea commercial port.Operationalization of Gwadar port would not only help to reduce the load on Karachi Port and Port Qasim but would also provide flexibility and balance to our maritime border security.Transformation of Gwadar into port city will attract foreign investments into SEZs and will become a catalyst for developmental activities thus will act as source ofbringing prosperity to Balochistan.

\section{- Speedy development of SEZs especially in Balochistan}

A significant amount of hope for progression of Balochistan is attached to CPEC and it will happenthrough establishment of SEZs. In total 28 $x$ SEZs have been planned in the country out of which $8 \times$ SEZs are planned in Balochistan. Speedy development of these SEZs will not only attract domestic and foreign investments but will also employ educated, semi-skilled and even unskilled workforce thus will reduce massive social burden.

\section{- Completion of Mega Projects as per planned timeline}

46http://tribune.com.pk/story/949098/regional-connectivity-iran-agrees-toconsider-being-part-of-cpec/

$47 \$ 600$ Billion Chinese investment in Iran over the next $10 \mathrm{yrs}$.
The completion of on-going mega projects as per given time line like Gwadar deep sea port, international airport at Gawadar, ${ }^{48} 6 \mathrm{x}$ small hydro dams, ${ }^{49}$ communication infrastructure, improved health 50 and education facilitieswill bringincredible economic and developmental activity in the province. It will definitelybe a step ahead towards achieving long term gains and will help in eradicating the socio-economic deprivation from the provinceby bringing foreign investment.

\section{- Prioritizing Small Developmental Projects gaining immediate effects}

Mega projects initiated by the present regime in the province would be able to bring their effects in longer run. Hence, there is a need to undertake smaller projects spread over complete province, so that people can be providedinstant relief by achieve short term gains.

- Conversion of $B$ Areas into A and Capacity Enhancement of Law Enforcement Agencies (LEAs)

There is an immediate need to convert " $\mathrm{B}$ " (semigo areas) areas into " $\mathrm{A}$ " areas (go-areas). This is not only important to institute the writ of the government but also to undertake the mega project as per planned timeline. During the process, getting away with old Khasadar System by instituting Police will of definitesignificance.

LEAs in Balochistan specially Police in first tier and Frontier Corps as second tier should be improved with enhanced capacity and proficiency to handle the circumstancesindependently, as the army's direct involvement in internal security matters does not go well while talking in overall context of suzerainty.

\section{- Educational Reforms}

People are required to be educated in order to broadentheir spectrum to think logically and deal at their own with impediments to the progress.

48 "New Gwadar International Airport, Pakistan". Airport Technology Retrieved 22 April 2019

49https://en.wikipedia.org/wiki/Small_hydro

50 The Pakistan Development Review by Pakistan Institute of Development Economics, Islamabad 
During the process, inherentlythey will also deal with the Sardari Nizam. People are also required to be motivated to send their children to schools. While doing this, standard of education needs to be improved by providing better facilities to educational institutions. In short term, special seats are required to be given in various public schools, Cadet Colleges and elsewhere in the country for young students of Balochistan. To bring the youth towards education, the cost of education also needs to be reduced or system of free education should be introduced. At the same time, madrassas, are required to be monitored and improved with the view to follow the correct and enlightened religious values.

\section{- Effective Cross Border Management}

Border management with Iran and Afghanistan will definitely improve with completion of "Border Fencing"and establishment of "Border Crossing Points" having proper infrastructure and government setup with the consent of both countries. It will not only check smuggling of oil and other banned items but will also add towards improved security and economic conditions. While doing this, there is a need to make available alternate options to the local people so that they can earn their livelihood with ease and respect.

\section{- Enrollment in Government Institutions} and Defence Forces

The youth from Balochistan has very lessenrolment in armed forces and representation at senior ranks. Likewise, government institutions have also very low intake, mainly due to low literacy and non-exposure outside Balochistan. In order to bring them into main stream, widespread enrollment drive may be carried out for enrolment in defense forces and government institutions from Balochistan with an aim to provide them better opportunities and exposure.

\section{- Effective Media Campaign and} applicability of Information Operations (IO) Tools
Anywhere in the world, sub-nationalists are sponsoreddue to beingill-informed andthe driveis basically given fuel due to this ignorance. To this end, media including electronic, print and social media must be used to informand guide people so that their capabilities can be governed towards right direction. As an immediate action, the federal government needs to make sure that Pakistan Television Broadcasts and mainstream periodicals are accessible in every part of the Balochistan to conveystance of government in local language. Meanwhile, designs and vested interests of external powers must be exposed through broadcasting well-articulated programs. At the same time,efforts putt in by the government towards generating economic programs through launching small scale and mega projects must be effectively transmitted to the people.This all would be required to be done with correct application of all IO tools taking into account on ground reality and public perception while countering negative propaganda being spread by sub nationalists under the influence of foreign powers.

\section{CONCLUSION}

Ultimately reforms are brought in to break the cycle of ferocity and violence.It is universal truth that masses would always oppose injustice and will fight for equality and justice. Secondly it is also well known fact that no one has ever given up power willingly or happily.

An amicable solution to the problems of Balochistan asks for comprehensive reforms in the current system of governance and political supervision. Better financial policies, enhanced political autonomy and effective administrationis need of the hour.In order to bring lasting solution,there is a need to take absolute nationalistic approach by federal as well as provincial government with zeal and deliberation.

\section{Limitations and future study}

There are few limitations to this study, primarily to keep the study focused and 
alive.First,the study is limited to future prospects of Balochistan, so the results of this study can only be used for further research on Balochistan. Secondly,statistics discussed in this study are not wholesome and comparative in numbers, hence there is a room available to expand the study and include wholesome comparative data for deeper analysis in future studies.

\section{REFERENCES}

[1] Siddiqi, Farhan Hanif (2012), the Politics of Ethnicity in Pakistan: The Baloch, Sindhi and Mohajir Ethnic Movements.

[2] Balochistan in focus-Rahimullah Yusufzai \& Balochistan, its Strategic importance-S Iqbal Ahmed

[3] Smith, Anthony D.Nationalism: Theory, Ideology, History. Cambridge: Polity Press

[4] Mansoor Akbar Kundi, "Tribalism in Balochistan: A Comparative Study," in Tribal Areas of Pakistan: Challenges and Responses (Islamabad: Islamabad Policy Research Institute and Hanns Seidel Foundation, 2005)

[5] Dashti, Naseer (2012), The Baloch and Balochistan: A Historical Account from the Beginning to the Fall of the Baloch State

[6] History of Balochistan(https://en.wikipedia.org/wi ki/History of Balochistan \# Pre Islamic history)

[7] The Dipolmat - Brief history article by Akhilesh Pillalamarri (https://thediplomat.com/2016/02/abrief-history-of-balochistan/)

[8] Muhammad Bin Qasim Predator or Preacher by Akhtar Balouch - Dawn 15 Dec 2020 \& Reliogion and Society in Arab Sindh by derryl N. Maclean

[9] M. Longworth Dames, "Balochi Folklore," Folklore 13, no. 3
(September 29, 1902): 252-74; Ibn Aseer 3: 17; Tarikh al Khulfa 1: 21415,229 .

[10] Syed Iqbal Ahmed, Blochistan, its strategic importance (2002)

[11] Ansar Abbasi "What Balochistan Deserves," The News International, (September 7, 2006)

[12] Pakistan: Elections held in 1988 InterParliamentary Union (http://archive.ipu.org/parlinee/reports/arc/2241_88.htm)

[13] T Boyce, "The China-Pakistan economic corridor: Trade security and regional implications," Sandia Report, California. (2017).

[14] CPEC Fact Book, 2016 \&https://reconnectingasia.csis.org/data base/projects/karachi-lahore-peshawarml1-rail-line-expansionrestoration/df56b152-7829-4b70-80fb$7508 \mathrm{c} 42281 \mathrm{~b} 0 /$

[15] "The History of Baloch and Balochistan: A Critical Appraisal," South Asian Studies, 32(1), (2017)

[16] UNDP Human Development Report, UNDP Human Development Report Office (2015)

[17] Government of Balochistan, "Chief Minister's Policy Reform Unit”, Balochistan Development Vision and Strategy (2014)

[18] Hafiz A. Pasha, Growth and Inequality in Pakistan-I, (Islamabad: Friedrich Ebert Stiftung, 2018)

[19] World Bank, "Pakistan-Balochistan Province: Public Financial Management and Accountability Assessment", Integrative Fiduciary Assessment No. 39799, (Washington DC 2013)

[20] Manzoor Ahmed and Akhtar Baloch, Political Economy of Balochistan, Pakistan: A Critical Review. European Scientific Journal, ESJ 11.14. (2015). 
Hafiz A. Pasha "Growth of the Provincial Economies," Institute for Policy Reforms, Islamabad, Pakistan (2015) http://ipr.org.pk/wpcontent/uploads/2016/04/GROWTHOF -PROVINCIAL-ECO-.pdf

[21] Aadil Nakhoda,"The 'E' in CPEC," Dawn Karachi, Mar 16 https://www.dawn.com/news/1246761

[22] UNDP Human Development Report 2015," UNDP Human Development Report Office, (2015)

[23] Kaiser Bengali and Aisha Ghaus Pasha, "Pakistan," in Ann L. Griffiths (ed.), Handbook of Federal Countries, for Forum of Federation, McGillQueen University, (2005) Moonis Ahmar, "Strategic Meaning of the China-Pakistan Economic Corridor," Strategic Studies, Vol. 28, No.4 (2014): 35-49

[24] http://www.finance.gov.pk/survey/chap ters_16/10_Education.pdf

[25] https://en.wikipedia.org/wiki/Small_hy dro

[26] The Pakistan Development Review by Pakistan Institute of Development Economics, Islamabad

[27] http://www.finance.gov.pk/survey/chap ters_19/Economic_Survey_2018_19.pd $\mathrm{f}$

[28] "New Gwadar International Airport, Pakistan". Airport Technology.

Retrieved 22 April 2019 